\title{
Floribec: the life and death of a tourism-based transnational community
}

Final revised manuscript of an article published in Norwegian Journal of Geography/ Norsk Geografisk Tidsskrift, vol. 65, no 1, 2011.

\section{Rémy Tremblay}

TELUQ, Université du Québec

100 Sherbrooke Street West

Montréal (Québec) Canada H2X 3P2

(819) 712-0360

tremblay.remy@teluq.uquebec.ca

\section{Hugues Chicoine, research assistant}

TELUQ, Université du Québec

455 du Parvis

Québec (Québec) Canada G1K 9H6

chicoine.hugues@teluq.uquebec.ca

\begin{abstract}
In this article, we outline how a tourist destination can morph into a tourism-based transnational community. We design a three-phase model exploring the touristification process of a transnational community. The phases are the adoption of a tourist destination, the transformation of this destination into a tourism-based transnational community, and decline under real estate and ageing population pressures.
\end{abstract}

Keywords

Floribec, ethnic tourism, transnational communities, development stages, decline. 


\section{Floribec: The life and death of a tourism-based transnational community}

Tourism and ethnicity are the object of an increasing number of studies. In the past thirty years, researchers specialising in this specific aspect of tourism and travel surveys have focused on ethnicity while an increasing number of scholars have analysed touristic activities in ethnic groups exiled from their countries. While urban problems and migrant ethnic communities are indirectly or implicitly inherent to social geography (Hardwick 2003; Ash 2007; Tremblay 2003b), geo-ethnicity was once defined as identities that match the administrative units in which the immigrant homelands are located. However, tourist migrants, and first-generation immigrants for that matter, do not or cannot lightly shed and abandon their cultural identity. The expression 'ethnic' ranks along with 'cultural' (speech, foods, fashion) and 'racial' characteristics and all three are aggregated in the expression 'minority', whether 'visible minority' is intended or not. Migrations and the scattering of ethnic groups now closely associate tourism with ethnicity, ethnic relations and ethnic identities and all three are aggregated under 'diasporas' (Coles and Timothy 2004, 13). However, in keeping with Rogers Brubaker's (2002) criticism of ethnic frameworks in research disciplines, 'identity', as well as 'group', are not finished concepts. In this article ethnic factors are limited to the cultural idioms of the visiting tourists, their cognitive schemas, organisational routines (vacationing tourists) and attending psychological processes of self-categorization.

Tourism must be counted among the migration pressures involved in globalisation, except that tourists are spenders, not job-seekers or displaced populations. Usually, every effort is made to maximize tourist activities, entertainment, spending, and length of stay. Although the economic side of the coin is determinative, it cannot account for individual motivations that drive tourism. The growth of leisure time in the 1970s, 1980s and 1990s has set a trend called 'VFR, visiting friends and relatives, e.g., ethnic reunions among migrant groups' (Page 2009, 71). Within a country like the U.S.A., ethnic tourism is on the rise and already, Asians, Hispanics and Black Americans sustain their own travel markets, products and habits (Whigham-Désir 1996, 130). Elsewhere, ethnic tourism is well established and is on the rise. Studies have been conducted on 
place identity in China and ethnic tourism (Oakes 1993), on ethnic tourism and nationalism in Wales (Pitchford 1995), into renegotiation of traditions in Indonesia (Adams 1997), in the commodification of ethnicity (Leong 1997), into the promotion of ethnic tourism in Mexico (van den Berghe 1995), and even from the standpoint of psychology whereby 'ethnic tourists may be balancing a desire for contact with such hosts against a concern over feeling uncomfortable when making choices of their ethnic tourism products' (Moscardo and Pearce 1999).

Ethnic tourism generally refers to a type of tourism where visitors from an industrialised country, seeking exotic experiences, travel to another country to visit and stay in a foreign 'ethnic' and cultural environment (Cohen 1993; Hitchcock 2001; King 1994; Ostrowski 1991). Persons who practice this type of tourism are often deemed superficial enough to hold prejudiced attitudes toward their hosts, for example tourists visiting the Aborigines in the Australian outback or the Inuits in the Canadian Arctic.

Other forms of ethnic tourism exist, generated by the presence of ethnic communities in the receiving country. The communities, usually established in urban environments in western countries, may be counted among touristic destinations, for example San Francisco’s Chinatown and New York's Little Italy; these highly visible communities are often the object of tourist gaze.

An increasing number of more recently established ethnic communities offer a meeting ground and exchange hub for newcomers to the community and for visitors from the generating country. Haitian communities in Montréal and Miami, and dozens of Mexican communities in the United States perfectly illustrate what Peggy Levitt calls transnational communities:

'Once we rethink the boundaries of social life, it becomes clear that the incorporation of individuals into nation-states and transnational connections are not contradictory social processes. Simultaneity is a possibility that needs to be theorized and explored. Rather than viewing migration as a one-way process, increasing numbers of scholars now recognize that migrants simultaneously live aspects of their lives in their outgoing countries at the same time that they are incorporated into the countries that receive them. Migrant incorporation into a new 
land and transnational connections to a homeland or to dispersed networks of family, compatriots, or persons who share a religious or ethnic identity can occur at the same time and reinforce each other.' (Levitt 2001, 3)

Now and then socio-cultural features of transnational communities become visible in the urban landscape, but the touristic component of the migration process had yet to be investigated. This article aims at shedding some light on the touristic extension of transnational communities. Using the case study of the Québécois in southeast Florida (Palm Beach, Broward and Dade counties) (Fig. 1), we construct an empirical model which explains and illustrates how a mass tourist destination such as Floribec can morph into a transnational tourist community. Although representative of the communities observed, a model is but a simplification.

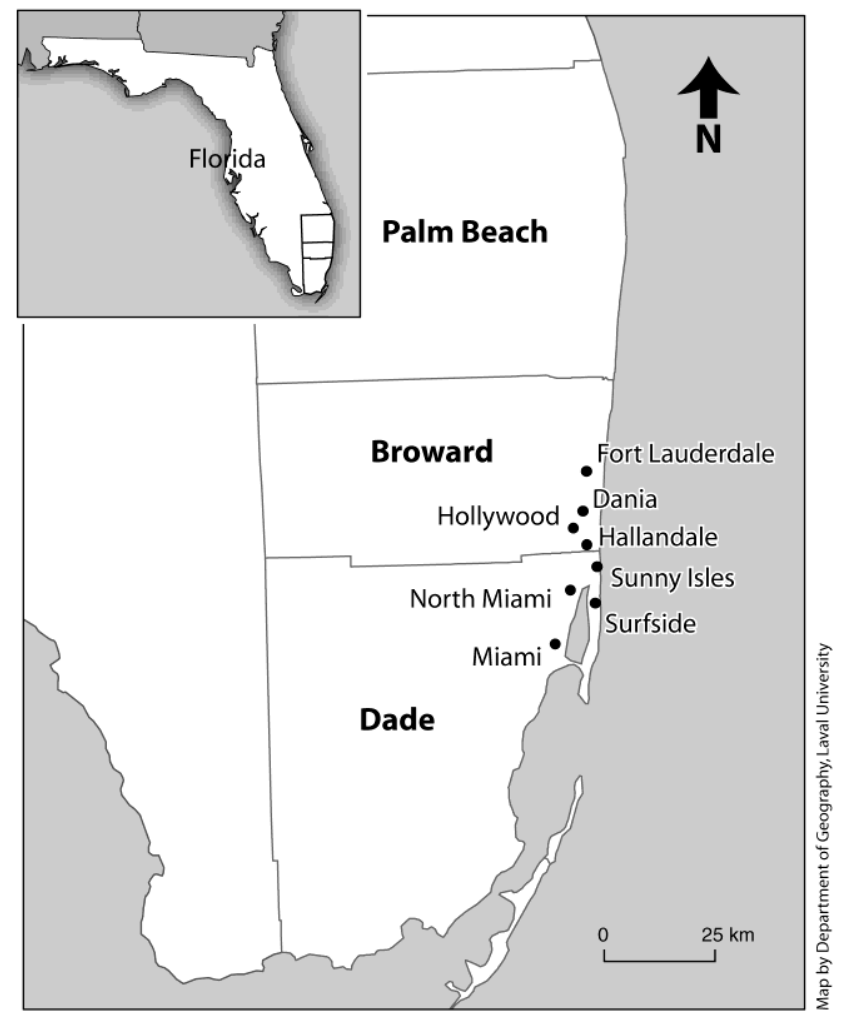

Figure 1: Floribec, a transnational tourist community established in three southeast Florida counties (Palm Beach, Broward and Dade). Map courtesy of the Geography Department, Laval University. 
The Floribec case study: The Québécois in southeast Florida.

There is extensive literature and studies on French America but research on the presence of Québécois in Florida is scarce (Tremblay 2003a, 2006). Floribec refers to a space occupied by migrants and tourists from Québec, most of whom belong to the working class. Economic activity and day to day life revolve mainly around Frenchspeaking tourists from Canada. The sector's rather blurred space (Fig. 2) extends over 5 kilometres in the Florida cities of Hollywood, Dania and Hallandale in the eastern suburb of the Miami metropolitan area.

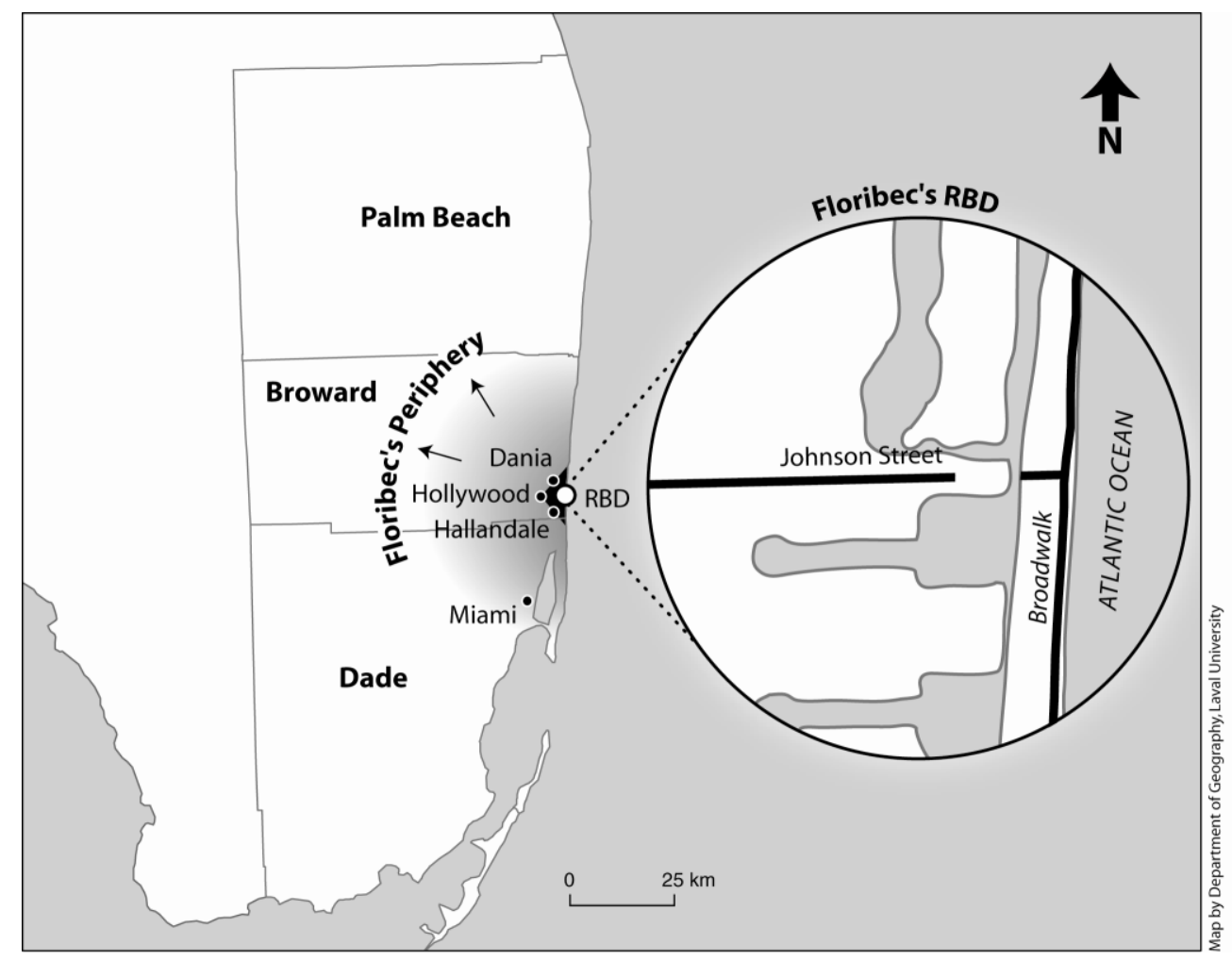

Figure 2: Activities and manifestations of the Floribec transnational tourist community are concentrated in a recreational business district (RBD) around Frenchie's Café. Map courtesy of the Geography Department, Laval University.

According to our investigation (Tremblay 2001), quite a number of businesses found along the string of three seaside suburbs cater to Québec migrants and tourists; the sector is designated under recreational business district or RBD (Stansfield and Rickert, 1970; Meyer-Arendt, 1990; Hall and Page, 2006). According to the 2000 U.S. census 
data, Miami accounted for approximately 25,000 Québec nationals. It is nevertheless believed that Florida's southeast coast attracts between 200,000 and 400,000 Québec tourists annually, by far Québec's first and preferred winter destination.

Floribec's spatial organization is visible in its display of hospitality and entertainment establishments. The ethno-touristic community in Floribec dates back to the 1970s, anchored in a recreational business district (RBD) located along the beach at Hollywood, Fla., including another more diffuse cluster of full-time foreign nationals. Beyond that nearby cluster, a peripheral population of migrants mingle with the ambient local suburban culture; among the long established migrants, few maintain any special connection to the Floribec community since their critical economic bonds tie them to the local American society.

In a way similar to the British in Spain's Costa Del Sol (O'Reilly 2000), the Floribec community thrives on its language and culture and maintains close relationships with the homeland in Québec. Tourist seasonal ebbs and flows play an overriding role in the resiliency of community life and much of this owes to telecommunications. For that matter, interactive information technologies -and not just the telephone- should be listed among social or cultural institutions if such category could exist. Access to television broadcasts is first and foremost a service offered to Québec tourists and the retailers who cater to them are acutely aware that this service is vital in attracting their patronage. The immigrants, i.e., those who have established permanent residence, as well as tourists from Québec, all relish the medium because television is vital for both. In short, according to our research, all forms of telecommunication instantaneously create a significant cultural link between the homeland and the newly found environment. The media are seen as a non tangible institution that brings to bear the original, although mediated, social and family network to this transnational community.

The Québec transnational community is vanishing. In the past five years at least, municipal authorities in Hollywood and Hallandale (Florida) have worked systematically and successfully to attract a wealthier client group. The built landscape is changing as well. What used to be Dade County is now Miami-Dade (Fig. 2), and the push is toward urban concentration (the distance from Miami to Fort Lauderdale is only 26 miles or 42 
$\mathrm{km})$. The touristic characteristics of Florida revolve around Miami's features not only as a seaside resort, but also as a worldwide destination for cruises in the West Indies; the Caribbean Sea area attracts 70\% of world cruises (Lozato-Giotard 2008, 24).

Miami's personality as an open seaside resort is urban and multipolar, and as such, it has a definite potential for renewal and adaptation to trends such as retired persons and the development of integrated hotel resorts (Lozato-Giotard 2008, 206), which also spells urban sprawl and population densification resulting in and depending on the concreting of the waterfront. Miami Beach and Dade county offer a typical historic example of such absent-minded development from the 1920s on, whereby already in the 1950s 'virtually every ocean front hotel had already run bulkheads, lines of cabanas or groins which fenced in their beaches' (Steinberg 1997, 427; see also Lozato-Giotard 2008, 231).

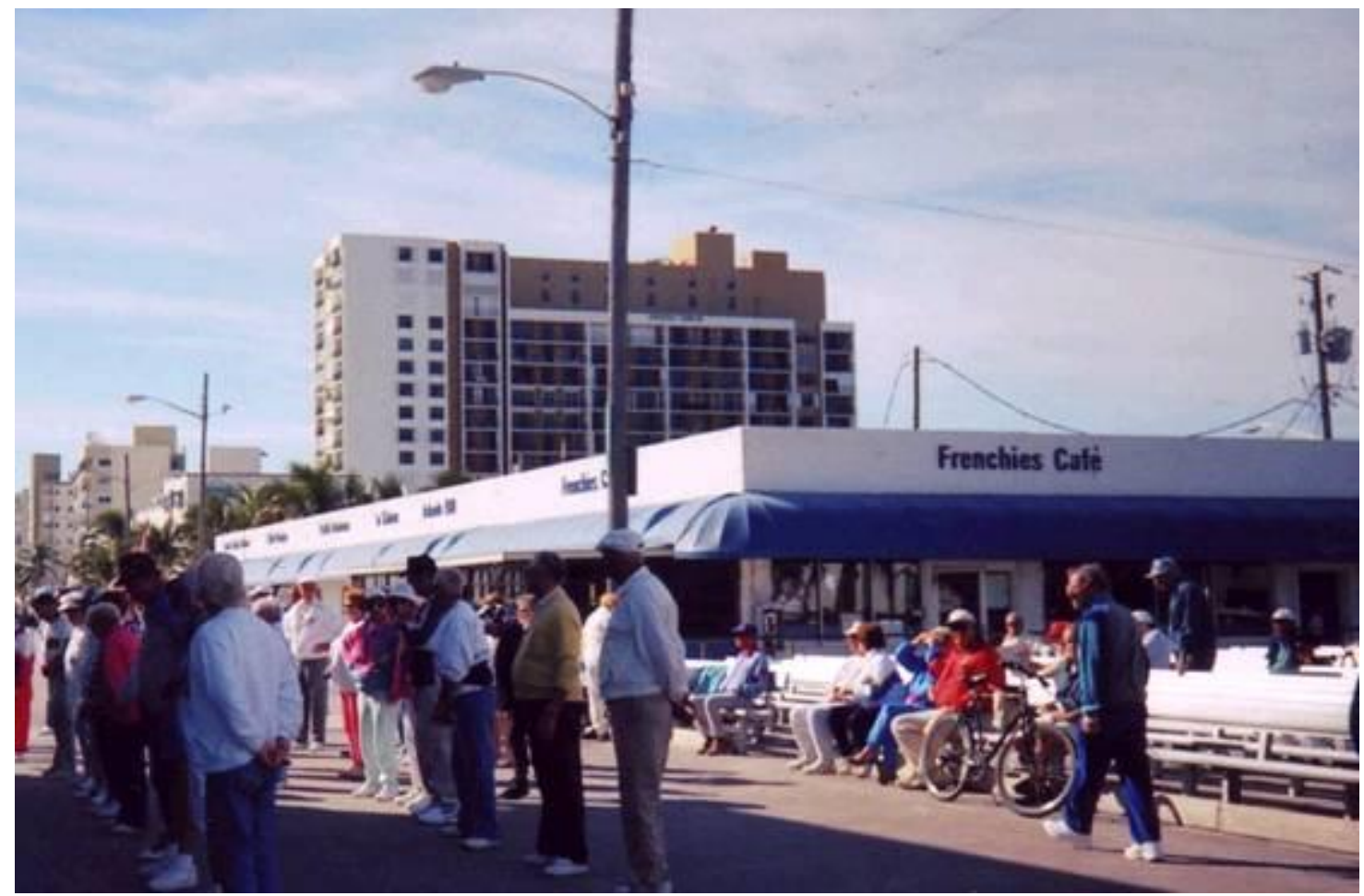

Figure 3: Frenchie's Café (now demolished) was the heart of Floribec's recreational business district (RBD). Photograph by Rémy Tremblay, circa 1994

Once a strip of low- and medium-rise motels (Fig. 3), hotels and buildings overlooking the beach, real estate development has systematically changed the coast to a string of high-rise condominiums (Fig. 4) which amounts to both gentrification and 
downtown-style suburban sprawl impacting the view from ground level and constraining access to the seaside.

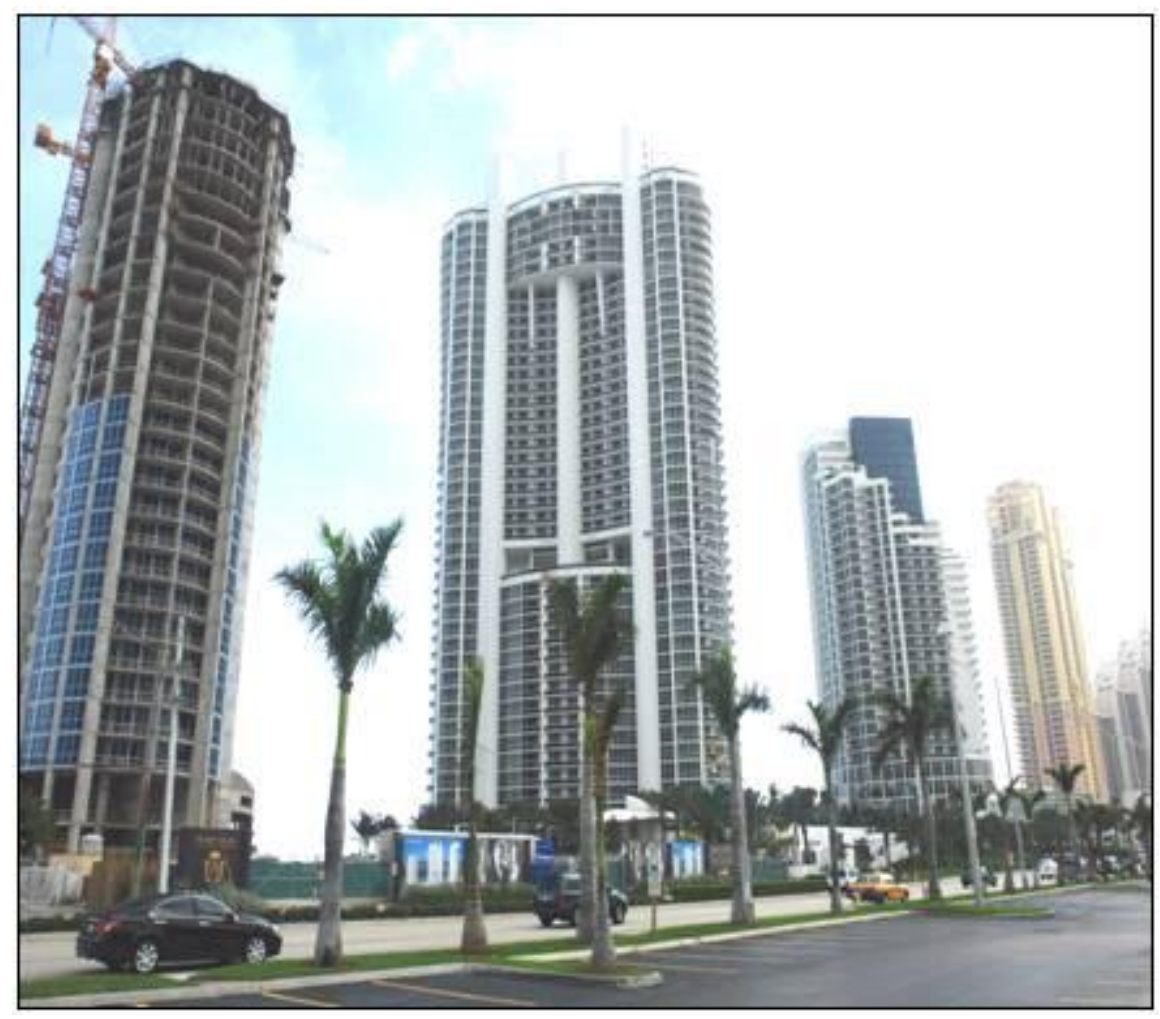

Figure 4: Towers on the waterfront in Sunny Isles. The building to the left (property of Donald Trump) was still under construction. (photograph by Rémy Tremblay 2006).

Further, more affordable tropical destinations are on the increase, in Cuba, the Dominican Republic and Mexico, and Québec tourists seem to be in the process of changing their habits from driving south to flying south. This quick overview of the Québec touristic phenomenon in Florida outlines what defines transnational-type communities according to Levitt: daily life in one's mother tongue is sustained and transactions with the homeland remain central. But how does a "sunshine destination" become a tourism-based transnational community?

\section{Modelling transnational tourism}

In 2002 the American geographer Dallen Timothy proposed a model entitled 'Urban Ethnic Islands Created by Tourism'. The model was captured and designed in the 
Little Finland established in Lake Worth-Lantana (Fla.) sixty miles $(100 \mathrm{~km})$ north of Miami; the research outlines how ethnic, touristic islands or sectors in urban areas are the product of either immigration as observed by Peggy Levitt (2001) as a result of her research, or an outcome of mass tourism. Table 1 outlines Timothy's interpretation of his findings. In Timothy's model, two scenarios may come to bear but both lead to a single result, in the second stage: the rise of urban ethnic islands created by tourism, i.e., a foreign touristic community enjoying enough recreation facilities and daily services provided in their language visibly displayed in the built environment.

\section{Scenario A: Ethnic touristic island created by immigration}

\section{First stage: urban ethnic island}

-arrival of the immigrants

-formation of the ethnic cluster

-development of the ethno-cultural space, environment

-specialization of leisure, recreational activities and of services

-preservation of language and traditions

Second stage: urban ethnic island created by tourism

-immigrants are tourists

-ethnic cluster is the touristic district

- cultural space is the touristic landscape

-specialized services intended for and provided to both local residents and tourists

-language and cultural activities within the cluster are those of the tourists as well.

Scenario B: Ethnic touristic island created by tourism

\section{First stage: Touristic destination}

-arrival of the tourists

-rise of the touristic district

-development of the touristic space, environment (or landscape)

-specialized services intended for and provided to the tourists

-residents learn the language spoken by the tourists

\section{Second stage: urban ethnic island created by tourism}

-tourists are the immigrants

-the ethnic cluster is the touristic district

-the cultural space is the touristic space, environment (or landscape)

-specialized services intended for and provided to both local residents and tourists

-language and the cultural activities within the cluster are also those of the tourists.

Table 1 - Villagization of transnational tourists. Twin scenario: ethnic urban island created by immigration (A), by tourism (B). 
In scenarios $A$ and $B$ the first stage differs on the grounds of the defining enclave, whether it is ethnic or touristic, although both will develop into an urban ethnic island created by tourism. In scenario A, the first stage refers to the known process whereby an ethnic community is established, and in scenario B the initial stage lies with an evolving touristic destination massively patronized by a foreign ethno-linguistic group until the sector becomes geosymbolically branded as a result.

Although this model is rather static and does not provide in this form all the details inherent to the evolving situations in our case study, we believe that scenario B is relatively sound and consistent with our observations. Both scenarios, however, do not take into account one of the fundamental aspects on which geographer Richard Butler had insisted: the life cycle and the possible decline of tourist destinations (Butler 1980). As was mentioned earlier, the outlook of the Floribec community seems rather dim at this point in time; it is near blanking, or depletion. We wish therefore to add a third stage to Timothy's (2002) scenario B, a decline stage (Table 2).

\section{First stage: Adoption of a touristic destination}

- arrival of the tourists -rise of the touristic district -development of the touristic space, environment (or landscape) -specialized services intended for and provided to the tourists -local residents learn the language spoken by the tourists Second stage: Transformation of the destination into an ethnic community -tourists are the immigrants -the ethnic cluster is the touristic district

-the cultural space is the touristic space, environment (or landscape) -specialized services intended for and provided to both local residents and tourists -language and the cultural activities within the cluster are also those of the tourists -information technologies are a decisive factor

Third stage: Decline of the transnational ethnic touristic community -spatial displacement of the touristic district

- the receiving community loses interest in the touristic community -closeout and/demolition of services -touristic community vanishes

Table 2 - Villagization of transnational communities observed in geographic case studies (adoption of destination, transformation, decline). 
We believe that some form of pattern exists in the priming of tourism in ethnic communities. We therefore wish to formulate our own description and explanatory model of the phenomenon which we call touristic priming in transnational communities (Table 3 ). The model accounts for three stages. The first stage identifies the adoption of a touristic destination within a delineated area or space (city, region, etc.) by an ethnolinguistic group other than that of the host country or region. In the second stage, a transformation occurs; the sector is still a mass destination for tourism but has become an ethnic community whose economy and daily life depend on the close and continued relationships with the country of origin (tourists, migrants and information technologies). In a third stage, a decline stage occurs. Causes may be as many as the effects involved and some transnational touristic communities may be immune to decline.

\section{Adoption}

A trans-border ethno-linguistic group massively adopts a touristic destination.

\section{Transformation}

Regular touristic and migratory contributions, communication technologies and the availability of services

transform a touristic destination into a transnational ethnic tourist community.

\section{Decline}

Competing touristic destinations

combined with different social phenomena - whether cultural or urbanbring about the decline of a transnational ethnic tourist community.

Table 3 - Touristic priming (massive adoption, regular contributions, decline due to competition or social/urban phenomena).

The Floribec phenomenon spans over fifty years and is not a linear experience. The first wave of Québécois migrants occurred between 1946 and 1960 in Surfside and Sunny Isles during the establishment years of mass tourism in Florida. Between 1960 and 1970, a second wave came about and Hollywood (Fla.) was the preferred destination while Florida's west coat underwent intensive development. From the 1970s to the 1990s, southern Florida witnessed an urban boom and a third wave of Floribec tourists invested in and bought condominiums as a result of the free trade agreement between Canada and the U.S.A. Since 2000, however, a number of hospitality buildings (motels, restaurants) were demolished in Hollywood and replaced with luxury hotels and condominiums. 
Floribec tourists relinquished Hollywood, Hallandale and Dania when several of their dedicated reference businesses folded.

Expansion, however, may not proceed uninterrupted and the process may enter a stagnation phase with economic decay, changes in lifestyle (activities and services), and/or a spatial displacement of the community. One of the drivers of change in tourism is real estate cycles. In the case of Florida, real estate alone cannot explain the process and as buildings replace buildings, people replace people and Florida is not the only place where tourism acquires another apparently permanent group of tourists: seniors. This generation driven phenomenon may well support and stabilize the tourism area life cycle (TALC) concept as it impacts on 'the development and supply of tourism infrastructure' (Hall and Page 2005, 355), e.g. the retired travel or second home quasi-permanent market.

\section{Conclusion}

Needless to say, no model is faultlessly fitting and any model remains perfectible. Nevertheless, the transnational community herein studied is similar to the Costa des Sol's British in several ways: they belong to identical socio-professional class, are of different ethno-linguistic origin, are deployed on separate continents and give rise to a pattern in the priming of tourism in transnational communities. In view of such salient configuration, we believe that the proposed model, inspired by the work of Dallen Timothy in a touristic perspective, could be a useful tool to understand socio-spatial and migrant behaviours of other groups. The model could be applied to political refugees and to marginalised and segregated groups in their quest for permanency. It could also shed light on social networks or diasporas and on tourist migration services available to ever mobile Westerners in developing and other Third World countries. 


\section{References}

Adams, K.M. 1997. Ethnic Tourism and the Renegotiation of Tradition in Tana Toraja. Ethnology, Vol. 36, No. 4 (Autumn), p.309-320.

Ash, A. 2007. Re-thinking the urban social. City: analysis of urban trends, culture, theory, policy, action, 1470-3629, Volume 11, Issue 1, p.100-114.

Brubaker, R. 2002. Ethnicity without groups. Archives européennes de sociologie XLIII [2]: 163-189.

Butler, R. 1980. The Concept of a Tourist Area Cycle of Evolution, Canadian Geographer, 24(1), p.5-12.

Cohen, E. 1993. The Study of Touristic Images of Native People: Mitigating the Stereotype of a Stereotype, in: R. Butler \&, D. Pearce (eds) Tourism Research: Critiques and Challenges, p.36-69. London: Routledge.

Coles, T.E. and Timothy, D.J. 2004 (Eds). Tourism, Diasporas and Space. London: Routledge.

Hardwick, S.W. 2003. Migration, embedded networks and social capital: towards theorising North American ethnic geography. International Journal of Population Geography. Special Issue: Migration: An American Human Drama. Volume 9, Issue 2 March/April, p.163-179.

Hall, C.M. and Page, S.J. 2006. The Geography of Tourism and Recreation. Environment, Place and Space. 3rd ed. Oxon (UK): Routledge.

Hitchcock, M. 2001. Anthropological Reflects on the Study of Tourism. In: G, Wall (Ed.) Contemporary Perspectives on Tourism, p.109-128. Waterloo: Department of Geography, University of Waterloo. Publication Series, Occasional Paper Number 17.

King, B. 1994. What is Ethnic Tourism? An Australian Perspective, Tourism Management, 15(3), p.173-176.

Leong, L.W.T. 1997. Commodifying ethnicity: State and ethnic tourism in Singapore. In: Picard, Michael \& Wood, Robert E., (eds), Tourism, Ethnicity and the State in Asian and Pacific Societies. Honolulu: University of Hawai'i Press, p.71-98. 
Levitt, P. 2001. The Transnational Villagers. Berkeley: University of California Press.

Lozato-Giotard, J.-P. 2008. Géographie du tourisme. De l'espace consommé à l'espace maîtrisé. 2e édition. Paris: Pearson Education.

Meyer-Arendt, K.J. 1990. Recreational Business Districts in Gulf of Mexico Seaside Resorts. Journal of Cultural Geography, Volume 11, Issue 1, September, p.39-55.

Moscardo, G. and Pearce, P.L. 1999. Understanding ethnic tourists. Annals of Tourism Research, Volume 26, Issue 2, 1 April, p.416-434.

Oakes, T.S. 1993. The cultural space of modernity: ethnic tourism and place identity in China. Environment and Planning D: Society and space 11(1) 47-66.

O'Reilly, K. 2000. The British on the Costa del Sol: Transnationallidentities and Local Communities. London: Routledge.

Ostrowski, S. 1991. Ethnic Tourism: Focus on Poland, Tourism Management, 12(2), p.125-131.

Page, S.J. 2009. Tourism management. Managing for Change. First edition. Oxford: Elsevier.

Pitchford, S.R. 1995. Ethnic tourism and nationalism in Wales. Annals of Tourism Research, Volume 22, Issue 1, p.35-52.

Steinberg, T. 1997. Do-It-Yourself Deathscape: The Unnatural History of Natural Disaster in South Florida. Forest History Society and American Society for Environmental History. Environmental History, Vol. 2, No. 4 (Oct.), p.414-438.

Tremblay, R. 2001. Floribec ou les Québécois en vacances. Montréal: Université du Québec, INRS-urbanisation, culture et société.

Tremblay, R. 2003a. Diversité de la géographie sociale. Canadian journal of regional science, XXVI:1 (Spring), 177-188.

Tremblay, R. 2003b. Le déclin de Floribec. Teoros: Revue internationale de recherche en tourisme/International journal of research on tourism, 22(1), pp. 18-27. 
Tremblay, R. 2006. Floribec, espace et communauté. Ottawa: Presses de l'Université d'Ottawa.

Timothy, D. 2002. Tourism and the growth of urban ethnic islands. In: Hall, C.M. and

Williams, A.M., Tourism and Migration. New Relationships between Production and Consumption. The GeoJournal Library. Dordrecht: Kluwer, p.135-168

Van den Berghe, P.L. 1995. Marketing Mayas: Ethnic tourism promotion in Mexico. Annals of Tourism Research, Volume 22, Issue 3, p.568-588.

Whigham-Désir, M. 1996. Ethnic travel is vital to American tourism. Black Enterprise, v27, December '96, p.130. URL (accessed August 2010, Google Books). 